\title{
Pendampingan Diversifikasi Produk Berbahan Baku Lele Asap di Desa Sampora, Tangerang
}

\author{
Kumala Indriati ${ }^{1}$, Linda Wijayanti ${ }^{2}$, dan Wibawa Prasetya ${ }^{3}$ \\ 1,2,3Fakultas Teknik Unika Atma Jaya, Tangerang Selatan, Indonesia
}

\begin{abstract}
ABSTRAK
Salah satu dari Tri Dharma Perguruan Tinggi adalah Pengabdian Kepada Masyarakat. Untuk melaksanakan kegiatan ini, Fakultas Teknik Unika Atma Jaya bermitra dengan Badan Usaha Milik Desa (BUMDES), Desa Sampora Tangerang. Program yang sudah dilaksanakan meliputi budidaya lele yang dimulai dari pembenihan, pembesaran dan pengolahan lele menjadi lele asap. Untuk meningkatkan ketrampilan ibu Rumah Tangga dalam melakukan diversifikasi produk, Tim pengabdian masyarakat memberikan penyuluhan dengan membuat produk berbahan baku lele, salah satunya pepes lele. Mengingat situasi pandemi covid-19 yang belum mereda, maka penyuluhan dilakukan secara online dengan jumlah peserta yang terbatas. Setelah melakukan pelatihan pengolahan berbagai menu dengan bahan baku lele, diharapkan nantinya berdiri warung makan yang dikelola oleh ibu-ibu dari Desa Sampora dengan menyediakan aneka menu dari lele.
\end{abstract}

Kata kunci: Tri Dharma Perguruan Tinggi; BUMDES; Lele Asap; Ibu RumahTangga; Covid-19

\begin{abstract}
One of Tri Dharma Higher Education goals is a community service. In order to generate this goal, Faculty of engineering of Atma Jaya Catholic University is collaborated with Village Owned Enterprises (Badan Usaha Milik Desa-BUMDES), Sampora Village, Tangerang. The program that has been implemented through cultivation of catfish which was commenced from catfish hatchery, growing and processing into smoked catfishes. In order to improve house wife skills in in a product diversification, the community service team has been providing mentoring program by creating a catfish product, which one of those is a catfish pepes (a cat fish dish wrapped in banana leaves). Furthermore, the mentoring program has been done for limited number of participants by online due to Covid-19 pandemic event. The training and mentoring program is aiming to create an opportunity for house wives in Sampora Village to start up a catfish food business in the area once the training has been completed.
\end{abstract}

Keywords: Tri Dharma Higher Education; BUMDES; smoked catfish; Housewife; Covid-19

\section{PENDAHULUAN}

Desa Sampora berlokasi di Tangerang Propinsi Banten. Pembangunan di daerah tersebut berkembang sangat pesat. Banyak lahan produktif berubah menjadi sentra bisnis, sehingga mendorong perubahan bagi masyarakat yang tadinya menggantungkan hidupnya terhadap hasil pertanian menjadi pengolah hasil pertanian dengan lahan yang terbatas. Salah satu usaha yang dapat dilakukan oleh warga desa Sampora dengan lahan terbatas adalah ternak lele. Usaha ini sudah dilakukan oleh masyarakat desa Sampora. Tetapi akhir-akhir ini mereka 
lebih suka menjual ternak lelenya pada usia 2-3 minggu, karena menurut mereka menjual bibit lebih menguntungkan daripada menjual lele pada usia siap panen.

Lele merupakan jenis ikan air tawar yang kandungan proteinnya melimpah. Selain protein, dalam daging lele terdapat juga asam omega 3. Zat ini bermanfaat bagi perkembangan otak pada janin. Budidaya lele dumbo pada umumnya diminati masyarakat Indonesia karena dianggap menguntungkan secara finansial. Dari sisi konsumen lele dumbo diminati karena terdapat kandungan gizi di dalamnya. Ikan lele merupakan salah satu sumber makanan yang mengandung nutrisi yang tinggi (Augustina et al, 2013). Kandungan nutrisi yang terkandung antara lain adalah protein, omega 3, asam amino, vitamin A, vitamin C, zatbesi, dan sebagainya. Omega 3 merupakan zat yang berguna untuk membantu pertumbuhan otak janin pada ibu hamil. Selain itu juga penting untuk pertumbuhan penglihatan mata dan saraf bayi. (Siyahailatua, 2019).

Setiap rumah makan pasti menyediakan olahan makanan yang terbuat dari ikan lele. Ikan lele selain memiliki cita rasa yang enak dan juga lezat ikan lele ini juga sangat baik untuk dikonsumsi karena mengkonsumsi lele ini memberikan dampak baik untuk kesehatan pada tubuh kita. Pada ikan lele memiliki kandungan vitamin B1, B2, protein, zatbesi, dan kandungan lainnya. Ikan lele merupakan salah satu komoditas budidaya yang memiliki berbagai kelebihan, diantaranya adalah pertumbuhan cepat dan memiliki kemampuan beradaptasi terhadap lingkungan. (Sitio et al., 2017)

Bahan pangan ikan mempunyai sifat mudah rusak karena adanya bakteri. Hal ini dapat terjadi karena tubuh ikan mengandung banyak air, menjadi media yang sangat cocok bagi pertumbuhan bakteri lain jika dibiarkan begitu saja tanpa dilakukan proses pengawetan. Pada saat jumlah produksi ikan lele meningkat berbagai olahan dilakukan untuk mempertahankan nilai gizi dan protein ikan lele, seperti pengolahan ikan lele asap (Sulfiani et al., 2018). Kegiatan pengabdian kepada masyarakat ini menitik beratkan pada pendampingan deversifikasi pengolahan lele menjadi menu masakan khas Desa Sampora dan pemasarannya di warung makan Puja Sera yang dikelola oleh BUMDES dan ibu-ibu Rumah Tangga di Desa Sampora, Tangerang

\section{TUJUAN PENGABDIAN}

Universitas Katolik Indonesia (UNIKA) Atma Jaya, khususnya Fakultas Teknik, melalui kegiatan pengabdian masyarakat ini telah menyediakan pendampingan dalam melakukan deversifikasi produk berbahan baku lele asap Dalam jangka panjang, tujuan kegiatan pengabdian ini adalah untuk memajukan usaha budidaya lele, lele asap dan bahan olahan lain yang berbahan baku lele asap, maupun lele segar. 


\section{MANFAAT PENGABDIAN}

Manfaat dari kegiatan pengabdian masyarakat ini adalah membekali masyarakat dalam hal ini membuka usaha makanan olahan berbahan baku lele, lele asap atau lele segar yang nantinya dapat menjadi makanan khas desa Sampora. Kegiatan pengabdian masyarakat ini juga menyediakan bantuan praktis berupa cara pemasaran lewat media sosial.

\section{METODOLOGI PELAKSANAAN}

Kegiatan pengabdian masyarakat dilaksanakan melalui beberapa tahapan yaitu:

\section{Survei Lapangan di Desa Sampora}

Survei lapangan di desa Sampora dimaksudkan untuk mengetahui pengetahuan masyarakat tentang bahan olahan lele. Hasil survey lapangan memberikan informasi bahwa masyarakat hanya tahu mengolah lele dengan cara digoreng, Mereka juga belum tahu bahwa lele dapat diawetkan dengan cara diasap. Melalui survei juga berhasil ditemukan tantangan utama yang dialami usaha budidaya lele, yaitu kurangnya pengetahuan tentang pemasaran dan dan pengolahan produk termasuk pengelolaan keuangan usaha.

\section{Tahap Pelaksanaan}

Pada tahap pelaksanaan dimulai dengan koordinasi dengan BUMDES, untuk mendata ibu-ibu PKK yang akan mengikuti pelatihan pengolahan Lele menjadi pepes lele daun kemangi. Kemudian pada saat tutorial tersebut di jelaskan bagaimana membuat Pepes Lele Daun Kemangi.

Berhubung keterbatasan waktu di masa pandemi covid 19, dan menghindari kerumunan anak-anak di sekitar pembuatan Lele Asap di desa Sampora maka pihak TIM Pengabdian Masyarakat setelah berunding dengan Pihak Desa Sampora diputuskan acara tutorial menggunakan lele segar dan dilaksanakan secara online, hasil pepes dikirim ke desa Sampora.

Adapun bahan-bahan membuat pepes lele daun kemangi adalah:

1. 6 ekor lele segar dibersihkan isinya, kerat-kerat dan bagi menjadi 2

2. 1 buah lemon dan $1 \mathrm{sdt}$ garam untuk merendam lele 
Gambar 1. Lele direndam lemon dan menumis

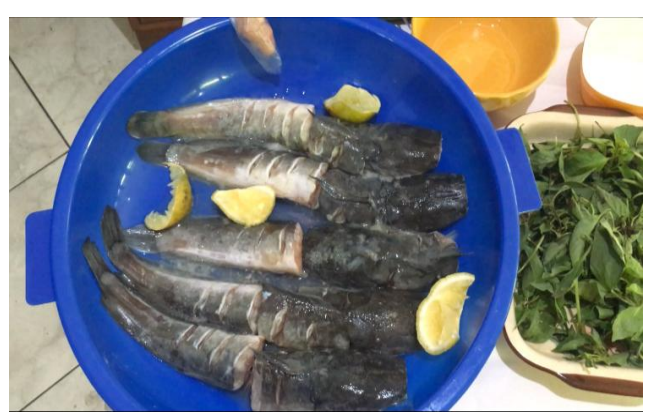

Gambar 2. Minyak untuk garam

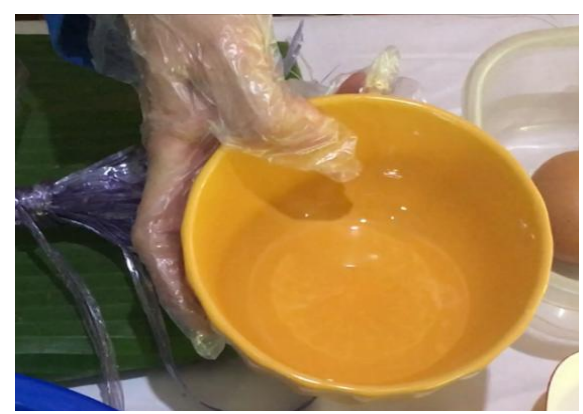

3. Sedikit minyak untuk menumis

4. Daun Pisang secukupnya (dipanggang di atas kompor supaya layu dan mudah untuk membungkus)

5. Tali rafia untuk mengikat pepes
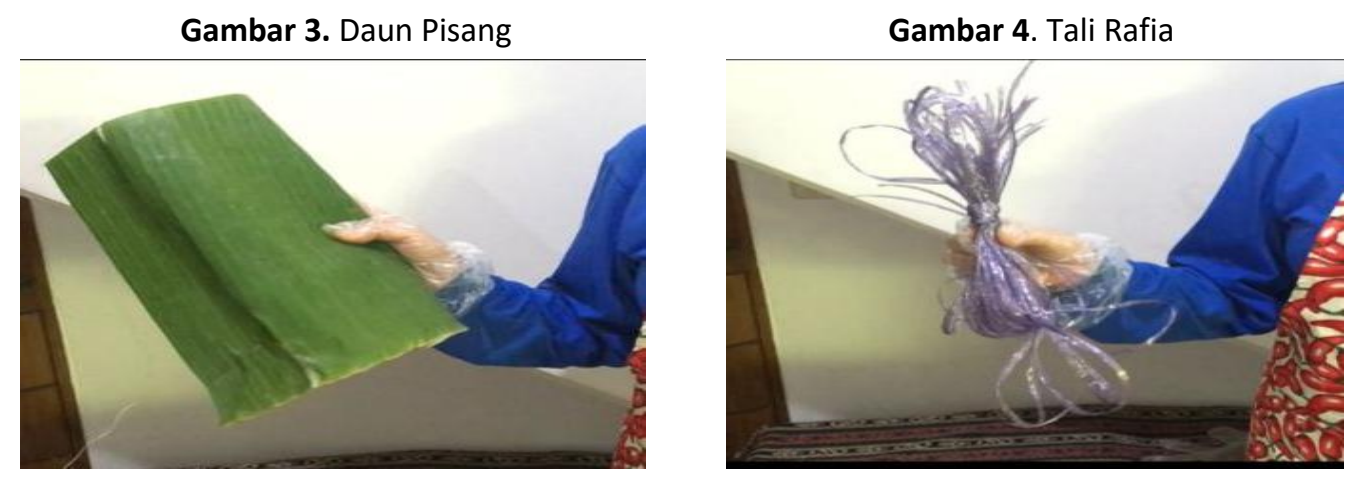

Bumbu A (Bumbu Halus): boleh diuleg atau diblender

1. 10 buah cabe merah besar (buang bijinya)

2. 10 siung bawang merah

3. 10 siung bawang putih

4. $2 \mathrm{~cm}$ jahe (kupas dan iris-iris)

5. $2 \mathrm{~cm}$ kunyit (kupas dan iris-iris)

6. $2 \mathrm{~cm}$ lengkuas (kupas dan iris-iris)

7. 12 butir kemiri

Gambar 5. Bumbu Halus

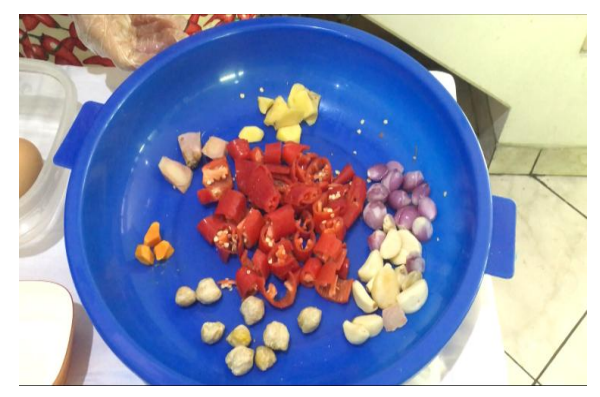

Gambar 6. Bumbu Tambahan

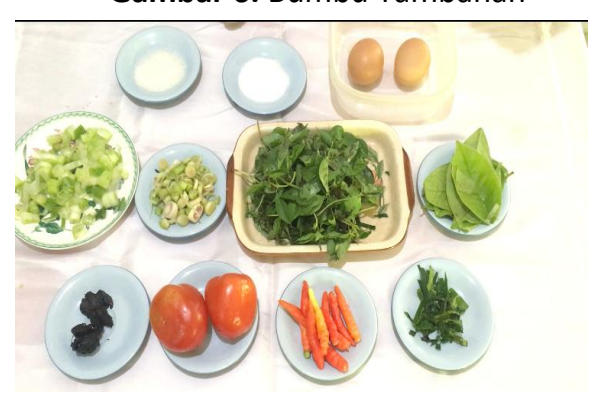




\section{Bumbu B (Bumbu tambahan):}

8. 5 sampai 10 lembar daun jeruk (sesuai selera), iris tipis tipis

9. 12 buah cabe rawit merah (atau sesuai selera)

10. 2 butir tomat merah (iris tipis-tipis)

11. 2 jumput asam jawa (encerkan dengan sedikit air hangat)

12. 12 lembar daun salam

13. 3 sampai 5 ikat daun kemangi (sesuai selera)

14. 3 tangkai sereh (iris tipis-tipis)

15. 3 batang daun bawang (iris tipis-tipis)

16. 2 butir telur (kocok)

17. 3 atau 4 sdt garam (sesuai selera)

18. 2 atau 3 sdt gula (sesuai selera)

\section{Langkah-langkah cara membuat pepes:}

1. Lele yang sudah dibuang isinya, kerat- kerat dan cuci bersih bagi menjadi 2

2. Lele diberi perasan lemon dan garam, diamkan selama 30 menit.

3. Haluskan bumbu A ( nomor 6 sampai dengan nomor 12 ) dengan menggunakan blender atau diuleg

Gambar 7. Bumbu A diblender

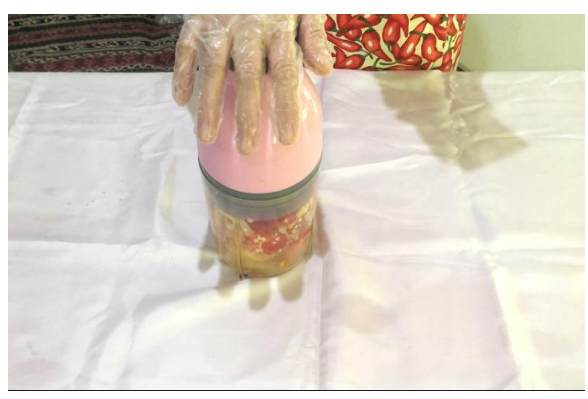

Gambar 8. Hasil setelah diblender

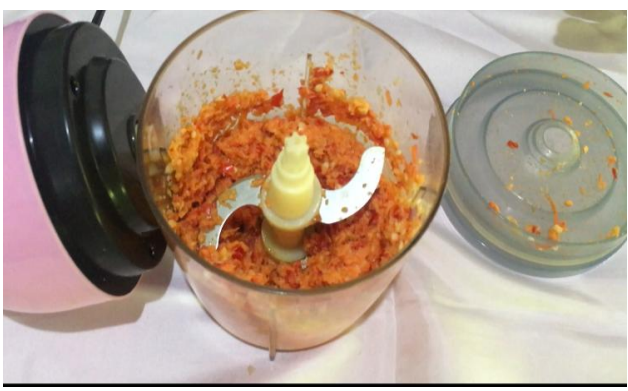

4. Tumis bumbu-bumbu tadi di atas wajan sampai tercium aroma harum

Gambar 9. Bumbu A ditumis

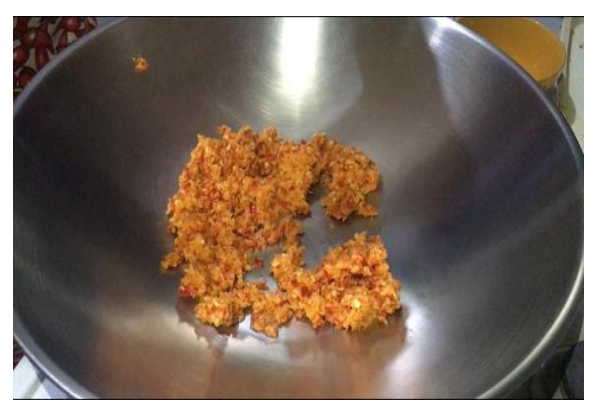

Gambar 10. Bumbu B dimasukkan

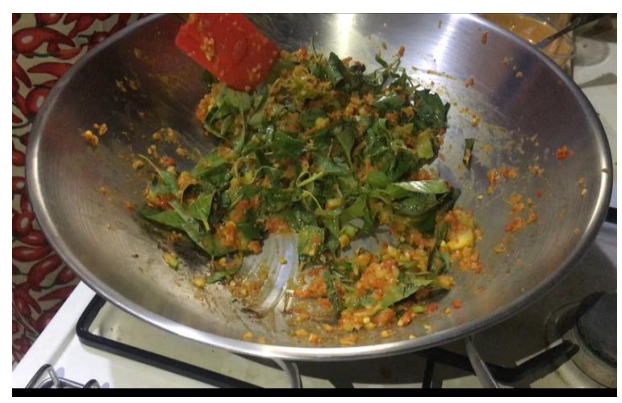

5. Masukkan irisan sereh, daun jeruk, aduk aduk

6. Masukkan irisan daun bawang, aduk aduk lagi

7. Masukkan perasan air asam, aduk aduk lagi 
8. Masukkan garam dan gula, aduk aduk lagi, cicip rasanya. Bila kurang manis atau asinnya boleh ditambah gula atau garam sesuai rasa yang pas.

9. Matikan kompor

10. Masukan kocokan telur ke dalam wajan, aduk lagi

11. Masukan daun kemangi, aduk-aduk lagi 2 bahan terakhir dimasukkan setelah api dimatikan dengan tujuan supaya telur tidak matang dan kemangi tidak terburu layu. 2 bahan tersebut akan matang saat dikukus.

12. Ambil 2 lembar daun pisang yang sudah dipanggang di atas kompor, ambil sesendok adonan bumbu letakkan sepotong lele bagian ekor, beri sesendok lagi adonan bumbu, tambahkan beberapa potong tomat dan 1 cabe rawit merah bungkus dengan daun pisang.

13. Lakukan dengan cara yang sama spt no 12 tetapi ambil lele bagian kepala, tambahkan beberapa potong tomat dan 1 cabe rawit merah, bungkus dengan daun pisang

Gambar 11. Lele dibungkus

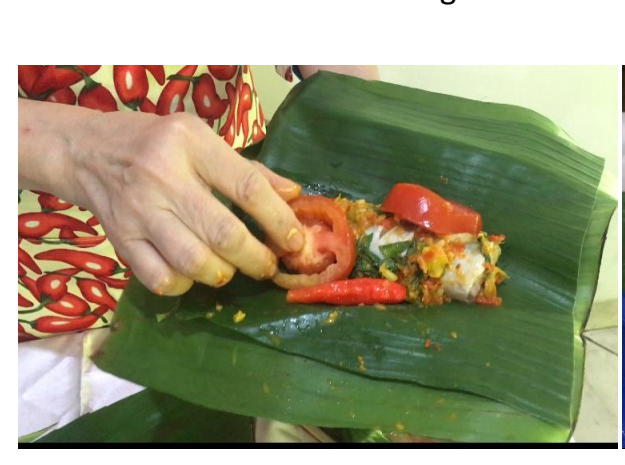

Gambar 12. Bungkusan lele diikat tali rafia

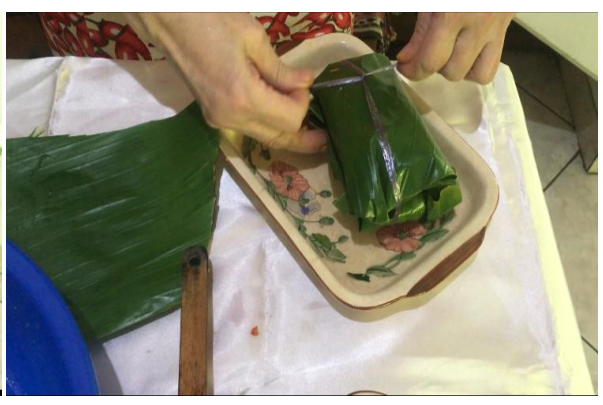

14. Kukus selama kurang lebih 30 menit

Gambar 13. Pepes mulai dikukus

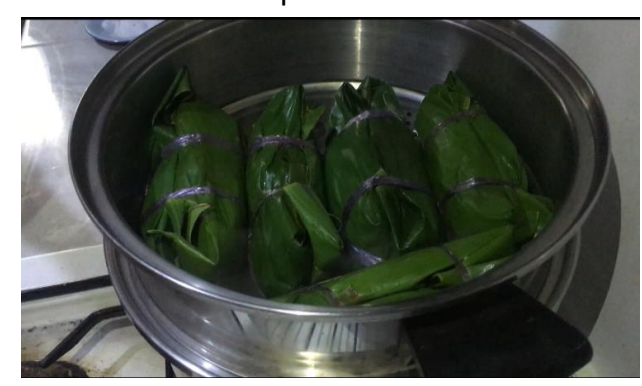

Gambar 14. Pepes selesai dikukus

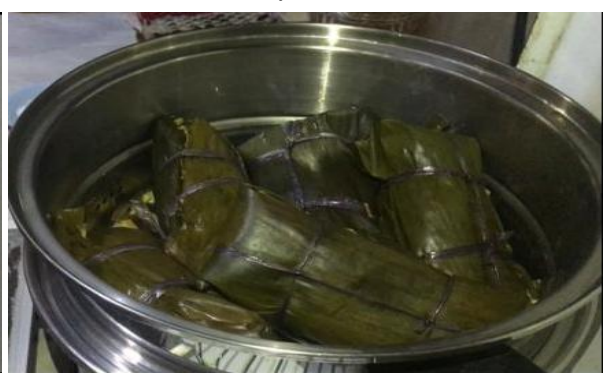

15. Setelah itu panggang di atas wajan ceper atau bakaran yang telah diolesin dengan minyak supaya hasil daunnya bagus berkilau 

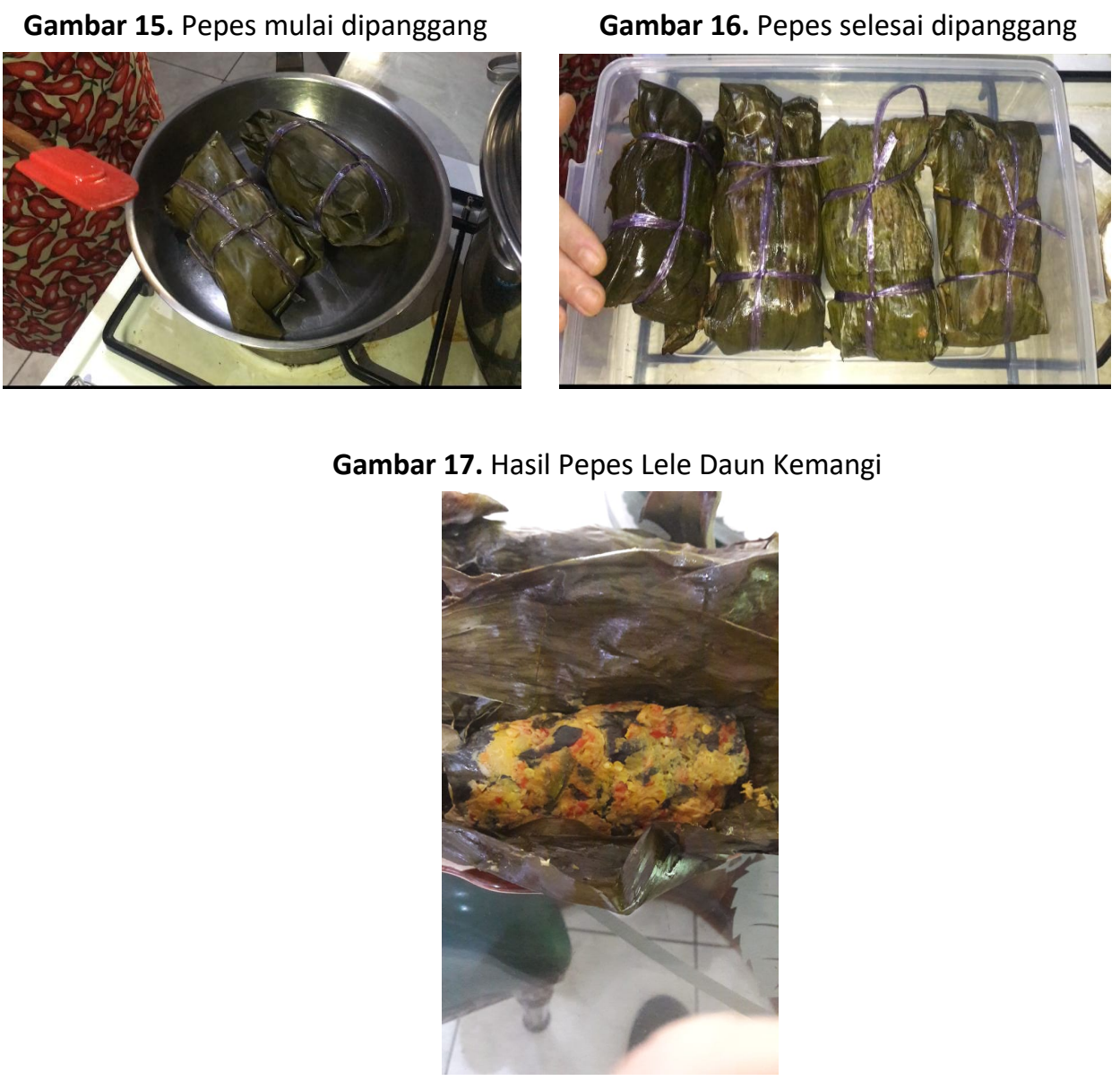

\section{HASIL DAN PEMBAHASAN}

Dari kegiatan pengabdian masyarakat yang telah selesai, kemudian dilakukan evaluasi dari segi proses pembuatan pepes lele. Peserta penyuluhan dapat mencoba masakan yang telah dibuat bersama sama sekaligus memberi penilaian tentang rasa, tampilan, proses yang telah dilakukan secara langsung.

\section{SIMPULAN}

Melalui kegiatan pengabdian masyarakat ini telah berhasil dilaksanakan pendampingan pemasaran dan pelatihan pembuatan laporan keuangan menggunakan aplikasi SI APIK. Pada kesempatan ini karena keterbatasan waktu, usaha masakan masih dalam taraf pengenalan 1 jenis masakan berbahan baku lele segar. Kami tim PengMas hanya memberikan tutorial satu jenis masakan tiap pertemuan, hal ini diharapkan agar lbu-ibu benar-benar dapat memahami dan tidak jenuh mengikuti acara tutorial ini, Untuk selanjutnya akan diperkenalkan jenis masakan yang lain berbahan baku lele asap maupun lele segar agar pengetahuan ibu ibu lebih bervariasi, yang pada akhirnya nanti dapat dikembangkan untuk usaha yang lebih besar seperti usaha kuliner secara online. 


\section{DAFTAR PUSTAKA}

Augustina, R., Syah, H., \& Ridha, M. (2013). Kajian Mutu Ikan Lele (Clarias batrachus) Asap Kering. Jurnal Teknologi dan Industri Pertanian Indonesia, 5(3), 6-11.

Sitio, M. H. F., Jubaedah, D., \& Syaifudin, M. (2017). Kelangsungan hidup dan pertumbuhan benih lele (clarias sp.) pada salinitas media yang berbeda. Jurnal Akuatur Rawa Indonesia, 5(1), 83-96. https://doi.org/10.36706/jari.v5i1.5810

Siyahailatua, S. E.D. (2019, Maret 13). 4 manfaat konsumsi ikan lele, proteinnya lebih tinggi dari susu. TEMPO.CO. https://gaya.tempo.co/read/1184678/4-manfaat-konsumsiikan-lele-proteinnya-lebih-tinggi-dari-susu/full\&view=ok

Sulfiani, Sukainah A., \& Mustarin, A. (2018). Pengaruh lama dan suhu pengasapan dengan menggunakan metode pengasapan panas terhadap mutu ikan lele asap. Jurnal Pendidikan Teknologi Pertanian, 3(Suplemen), 93-101. 